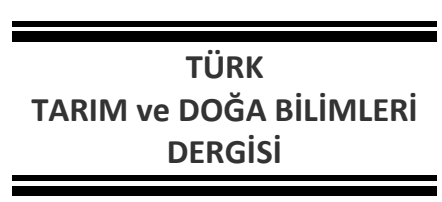

\title{
Ortaokul Öğrencilerinin Mekâna Bağlı Serbest Zaman Aktivite Tercihleri ve Rekreasyonel Eğilimleria $^{\mathrm{a}}$
}

\author{
Hüccet VURAL ${ }^{1 *}$, Sevgi YILMAZ² \\ ${ }^{1}$ Bingöl Üniversitesi, Ziraat Fakültesi, Peyzaj Mimarlığı Bölümü, Bingöl \\ ${ }^{2}$ Atatürk Üniversitesi, Mimarlık ve Tasarım Fakültesi, Peyzaj Mimarlığı Bölümü, Erzurum \\ *Sorumlu yazar: huccet_vural@hotmail.com
}

Geliş Tarihi: 21.03.2018

Düzeltme Geliş Tarihi: 06.08.2018

Kabul Tarihi: 06.08.2018

\section{Özet}

Merkezi sınava dayalı eğitim politikaları ve yoğun ders programları öğrencilerin zamanlarının büyük kısmını eğitim öğretim faaliyetlerine ayırmalarına neden olmaktadır. Öğrencilerin özgürce oyun oynayabilecekleri ve çeşitli rekreasyonel aktiviteler yapabileceği serbest zamanı oldukça sınırlı kalmaktadır. Araştırmada öğrencilerin zaman değerlendirme biçimleri, oyun ve serbest zamanları ile ilgili mekân ve aktivite tercihlerinin belirlenmesi amaçlanmıştır. Tarama yönteminin kullanıldığı araştırmada veriler Erzurum ili Palandöken illçesinde bulunan Kayak Yolu Çimento Müstahsilleri İşveren Sendikası Ortaokulu'nda eğitim gören 282 öğrenci ile yüz yüze yapılan anket çalışmasından elde edilmiştir. Elde edilen veriler öğrencilerin \%59'unun serbest zamanlarını dış (açık) mekânlarda geçirmeyi tercih ettikleri, açık alanda öğrencilerin sportif aktiviteleri (\%43.6), kapalı alanda ise aile ve arkadaşları ile zaman geçirmeyi (\%29) en fazla tercih ettikleri görülmüştür. Cinsiyete göre açık ve kapalı mekan rekreasyon tercihlerinde farklılıkların olduğu, erkek öğrencilerin fiziksel aktiviteye dayalı aktif rekreasyonu, kız öğrencilerin ise az hareketli yaşam tarzına uygun pasif rekreasyonu daha fazla tercih ettikleri belirlenmiştir. Bu sonuçlar doğrultusunda cinsiyete göre tercihler göz önünde bulundurularak öğrencilerin serbest zamanlarını etkin ve verimli geçirecek şekilde fiziki planlamaların yapılması gerekliliği vurgulanmıştır.

Anahtar kelimeler: Aktivite, anket, ortaokul öğrencisi, rekreasyon, serbest zaman.

\section{Secondary School Students' Choices of Free Time Activities and Recreational Tendencies Based on Place}

\begin{abstract}
Educational policies based on central examination and intensive academic programs cause students to spend most of their time on education. The amount of their free time when they can play games freely and do various recreational activities is limited. This study aims to investigate students' ways of spending their time and their choices of place and activity with respect to playing and free time. The data for this research, using the scanning method, was received from a face-to-face survey on 282 students in Kayak Yolu Çimento Müstahsilleri İşveren Sendikası Secondary School, located in Palandöken, Erzurum. The data shows that 59\% of the students prefer to spend their free time outdoors, and while they tend to do sport activities outdoors (43.6\%), they are more likely to spend time with their families and friends indoors (29\%). It has also been determined that recreational choices are different for outdoor and indoor places; male students prefer active recreation based on physical activities, and female students prefer passive recreation based on their less active lifestyle. In accordance with these results, it has been emphasized that schools must be physically planned to provide students with enough opportunities for spending their free time efficiently, taking their choices based on gender into consideration.
\end{abstract}

Key words: Activity, survey, secondary student, recreation, free time. 


\section{Giriş}

İnsan hayatının en önemli değerlerinden birisi zamandır. Zamanın etkin ve verimli kullanılması kişiye önemli kazanımlar sağlar. Diğer taraftan zamanını iyi değerlendiremeyen bireyler hayattaki hedeflerine ulaşmakta güçlük çekerler. Bu nedenle zamanın iyi kullanılması ve değerlendirilmesi için insanlara başta eğitim olmak üzere farklı destekler ve imkânlar sunulmalıdır. Özellikle örgün eğitimde okul öncesi eğitimden yükseköğretime kadar öğrencilerin etkili ve verimli zaman planlanması konusunda bilinçlendirilmesi gerekmektedir. Ne yazık ki merkezi sınava dayalı eğitim politikalarımız ve yoğun ders programlarımız öğrencilerin zamanlarının büyük kısmını okulda ve evde ders çalışarak, ödev yaparak veya test çözerek geçirmesini zorunlu kılmıştır. Dolayısı ile eğitim öğretim sezonunda öğrencilerin özgürce oyun oynayabileceği, dinlenebileceği veya çeşitli aktiviteler yapabileceği serbest zamanı oldukça sınırlı kalmaktadır.

Corbin (1970) ve Ragheb ve Tate (1993)'e göre ise serbest zaman; bireyin dıştan gelen zorlamalara bağıı kalmadan özgür iradesi ile seçtiği ve belirli kurallara bağlı olmadan eğlenme, hoşlanma ve mutluluk duygusu uyandıran, fiziksel, zihinsel ve ruhsal olarak yeniden hazır hale gelmek için ayrılan zaman aralığıdır. Serbest zamanlarında bireyler fiziksel ve ruhsal gelişim, sosyalleşme, dinlenme, rahatlama ve sağlıklı olma gibi farklı gerekçelerle çeşitli etkinlikler yapmaktadır. Serbest zamanda bireyin yaptığı etkinlikler serbest zaman etkinlikleri veya rekreasyon aktiviteleri olarak adlandırılmaktadır (Ardahan ve Lapa, 2011). Dolayısı ile serbest zaman ve rekreasyon terimleri birbirini tamamlamaktadır. Rekreasyon latince bir kelime olup 're-tekrar, yeniden' ve "create-yaratma, yenileme" anlamına gelen sözcüklerin birleşmesinden oluşmuştur. Tükçe olarak 'serbest zamanları değerlendirme biçimi olarak tanımlanmaktadır (Kalem, 2001; Şahin ve ark., 2009). Diğer bir tanıma göre ise rekreasyon, bireyin serbest zamanında kendi isteği ile yaptığı, ruhsal ve fiziksel yönden yenilenmeyi amaçlayan, ekonomik ve kültürel olanakları ile yaşadığı toplumun yapısına bağımlı olarak yapılan etkinliklerin tamamı olarak tanımlanmaktadır (Şahin ve ark., 2009). Rekreasyon stresin azaltılması, doğal ve kültürel çevrenin tanınması, kişisel ve toplumsal kimliğin tanınması ve çevre ile ilgili konularda sorumluluk alma davranışları kazandırma gibi çok önemli katkıları bulunmaktadır (Grahn ve Stigsdotter, 2003; Kil ve ark., 2014).

Serbest zamanların değerlendirilmesi ve rekreasyonel ihtiyaçların karşılanmasında mekân faktörünün etkisi büyüktür. Pehlivanoğlu (1986), rekreasyonel etkinliklerin sürdürüldüğü mekâna göre iç/kapalı mekân ve dış/açık mekân rekreasyonu şeklinde iki karşıt sınıflama yapmıştır (Müderrisoğlu ve Uzun, 2004). Kapalı mekân rekreasyonu ev, okul, alışveriş merkezleri, vb iç mekânlarda gerçekleşen aktiviteleri, açık mekân rekreasyonu ise kentsel açık ve yeşil alanlarda gerçekleşen aktiviteleri içermektedir. Özellikle kentsel açık ve yeşil alanlar insanların sağlıklı bir ortamda yaşamasına ve rekreasyonel eylemlerin gerçekleşmesine önemli katkılar sunmaktadır (Cengiz ve Doğtaş, 2015).

Serbest zamanların değerlendirilmesi ve toplumun rekreasyon ihtiyaçlarının karşılanması giderek önemli bir sorun haline gelmiş ve buna yönelik araştırmalar yapılmıştır. Artık yalnızca çalışanların değil, iktisaden pasif nüfusun; çocukların ve gençlerin boş zamanlarını en iyi biçimde nasıl değerlendireceği üzerinde çalışılmaktadır (Ayaşlıgil ve Kubat, 2005). Bunun yanında rekreasyon farklı meslek grupları tarafından ele alınmaktadır. Beden Eğitimi, Sosyoloji, Coğrafya, Turizm gibi çeşitli Sosyal Bilimler alanları ile Peyzaj Mimarlığı, Şehir ve Bölge Planlama gibi Fen Bilimleri alanlarında çok sayıda araştırma yapılmıştır. Ayaşlıgil ve Kubat (2005), Yaman ve Arslan (2009), Ardahan ve Lapa (2011), Metin ve ark. (2013), Cortes ve ark. (2017) sosyal alan çalışmasına, Mansuroğlu (2002), Grahn ve Stigsdotter (2003), Müderrisoğlu ve Uzun (2004), Kiper (2009), Şahin ve ark. (2009); Talay ve ark. (2010), Metin ve ark. (2013), Tyrvainen ve ark. (2013), Kil ve ark. (2014), Sağlık ve Kelkit (2014), Cengiz ve Doğtaş (2015), De Valck ve ark. (2017) fen bilimi alan araştırmasına örnek teşkil etmiş ve bu araştırmaya kaynak teşkil etmiştir.

Örgün eğitim öğrencilerinin serbest zaman değerlendirme biçimi ve rekreasyonel eğilimleri ile ilgili yapılan araştırmaların çoğu üniversite öğrencilerine yönelik olup ilköğretim öğrencilerinin serbest zaman aktiviteleri ve rekreasyonel eğilimlerine yönelik çok az sayıda araştırma literatürde yer almaktadır. Oysa ilköğretim öğrencileri için serbest zamanlarını değerlendirme biçimi son derece önemlidir. Bu yaş grubu çocuklar için en temel serbest zaman aktivitesi ise oyundur. Oyun oynamak çocuklar için, sosyal, fiziksel ve kavramsal gelişim konusunda en iyi eğitim programıdır. Bunun yanında iyi tasarlanmış ve iyi yönetilen bir oyun alanı; çocuklara motor becerilerinin geliştirilmesi, sosyal gelişim, öğrenme, karar verme ve yaratıcı oyun oynama gibi gelişim fırsatları tanımaktadır (Alqudah, 2003; Ünal, 2009). Dolayısıyla serbest zaman, rekreasyon ve oyun kavramları birbirini tamamlayan kavramlardır.

$\mathrm{Bu}$ araştırmanın temel amacı toplumun yarınını oluşturacak olan bugünün çocuklarının zamanlarını değerlendirme biçimleri, serbest zaman 
aktivite tercihleri ve rekreasyonel eğilimlerini belirlemektir. Bunun yanında öğrenciler için önemli rekreasyon aktivitesi olan oyun için mekan ve zaman ihtiyaçları da belirlenmeye çalışılmıştır. Araştırmada başta ebeveynler olmak üzere eğitimcilere, karar vericilere, fiziki planlamada çalışan meslek gruplarına ve akademisyenlere farklı bakış açısı kazandırmak hedeflenmiştir.

\section{Materyal ve Yöntem \\ Materyal}

Araştırmanın materyalini Erzurum il merkezinde bulunan Palandöken İlçe Milli Eğitim Müdürlüğüne bağlı Kayak Yolu Çimento Müstahsilleri İşveren Sendikası Ortaokulu'nda eğitim gören öğrenciler oluşturmaktadır. Araştırmada serbest zaman aktivite tercihleri ve rekreasyon eğilimlerin belirlenmesine yönelik ulusal ve uluslararası literatürden yararlanılmıştır.

\section{Yöntem}

Araştırmada betimsel bir araştırma yöntemi olan tarama (sörvey) yöntemi kullanılmıştır. Veri toplama aracı olarak standart anket formu oluşturulmuştur. Anket sorularının hazırlanmasında öğrencilerin dikkat süreleri ve Milli Eğitim Bakanlığı tarafından belirlenen bir ders saati şartına uygun olarak kısa hazırlanmıştır. Anket taslakları için 3 öğretim üyesi, 1 okul yöneticisi, 2 öğretmen ve 1 öğrenci velisi olmak üzere 7 kişiden uzman görüşü alınmıştır. Uzman görüşü sonrasında örneklem dışında kalan 12 öğrenciye ön anket uygulama yapılmıştır. Anketlere son şeklinin verilmesinden sonra II Milli Eğitim Müdürlüğü'nden uygulama izni alınmış ve 11 Ocak 2017 tarihinde okul öğretmenlerinin yardımıyla ders esnasında uygulanmıştır (Şekil 1).
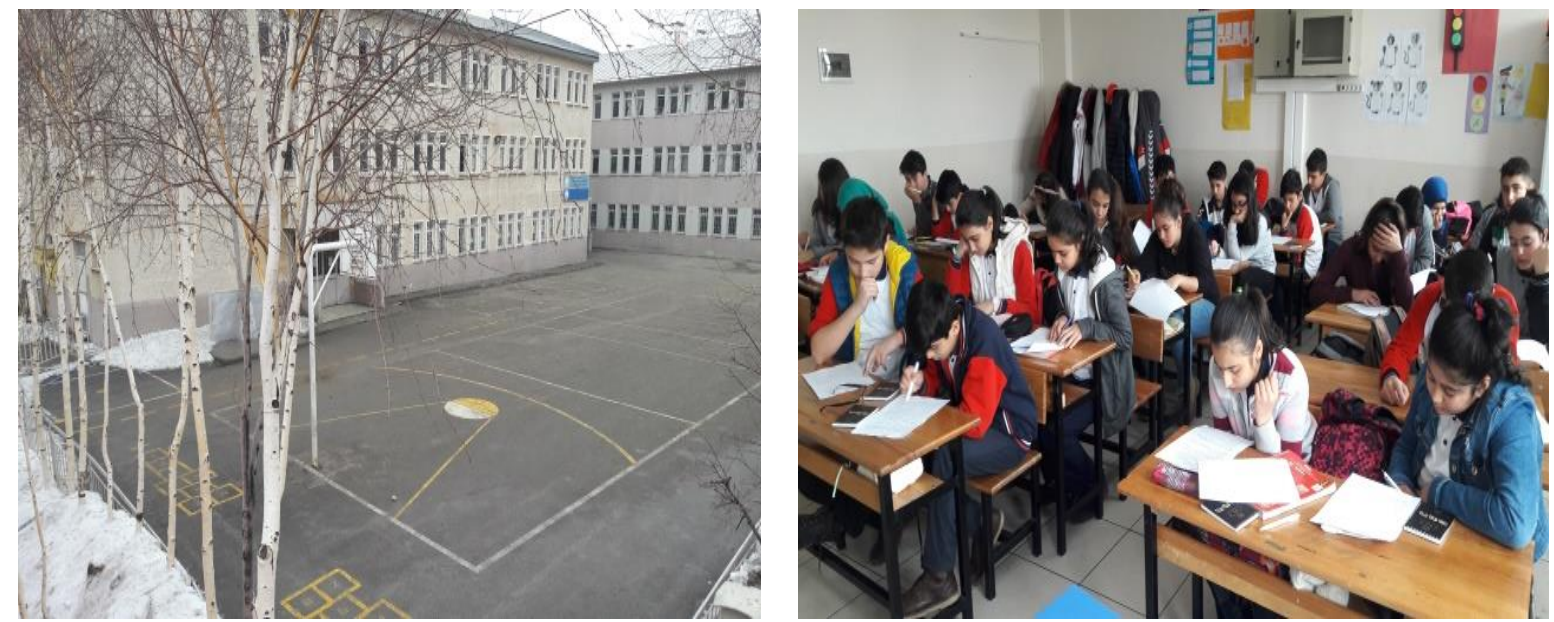

Şekil 1. Anket yapılan okuldan ve anket anından görünüm.

Anketlerin ortalama cevaplama süresi $20-30$ dakika arasındadır. Örneklemin belirlenmesinde basit tesadüfü yöntem kullanılmış ve rastgele belirlenen 8 sınıfta uygulanmıştır. Buna göre ankete 146 kız öğrenci (\%51.8), 136 erkek öğrenci (\%48.2) olmak üzere toplam 282 öğrenci katılmıştır. Öğrencilerin sınıflara göre dağılımları ve evren içerisinde temsil edilme yüzdeleri ise Çizelge 1 'de verilmiştir.

Çizelge 1. Ankete katılan öğrencilerin sınıflara göre dağılımları ve evren içerisinde temsil edilme yüzdeleri.

\begin{tabular}{ccccc}
\multirow{2}{*}{ Sınıflar } & \multirow{2}{*}{ Toplam öğrenci sayısı } & \multicolumn{2}{c}{ Ankete katılan öğrenci } & \multirow{2}{*}{ Sınıflara göre temsil edilme yüzdesi (\%) } \\
\cline { 3 - 4 } & & Sayısı (f) & Yüzdesi (\%) & 24.23 \\
\hline 5. Sınıf & 326 & 79 & 28 & 33.63 \\
6. Sınıf & 220 & 74 & 26.2 & 29.13 \\
7. Sınıf & 230 & 67 & 23.8 & 29.24 \\
8. Sınıf & 212 & 62 & 22 & $\mathbf{2 8 . 5 4}$ \\
\hline Toplam & $\mathbf{9 8 8}$ & $\mathbf{2 8 2}$ & $\mathbf{1 0 0}$ & \\
\hline
\end{tabular}

Anket çalışmasından elde edilen veriler SPSS18 paket programı aracılığı ile analiz edilmiştir. Verilerin analizinde betimsel istatistik ve kategorik veriler istatistik analiz yöntemlerinden (Pearson chi square) yararlanılmıştır.

\section{Bulgular ve Tartışma}

Araştırmanın bulguları öğrencilerle yapılan anket sonuçlarına dayanmaktadır. Anket sonuçları iki başlık altında incelenmiştir. 


\section{Öğrencilerin zaman değerlendirme biçimleri}

'Aşağıdaki aktivitelere hafta içi bir günde okul saati dışında ortalama ne kadar zaman ayırırsınız?
Uygun bir seçeneği işaretleyiniz.' şeklinde sorulan soruya öğrencilerin verdiği cevapların frekans ve yüzdelik değerleri Çizelge 2'de verilmiştir.

Çizelge 2. Öğrencilerin hafta içi bir günde zaman kullanma biçimleri.

\begin{tabular}{|c|c|c|c|c|c|c|c|c|c|c|}
\hline \multirow[t]{2}{*}{ Aktivite } & \multicolumn{2}{|c|}{$\begin{array}{c}\text { Bazı günler/ } \\
\text { Çok az veya } \\
\text { hiç (1) }\end{array}$} & \multicolumn{2}{|c|}{$\begin{array}{c}\text { Günde 0-30 } \\
\text { dakika (2) }\end{array}$} & \multicolumn{2}{|c|}{$\begin{array}{c}\text { Günde } \\
30-60 \\
\text { dakika (3) }\end{array}$} & \multicolumn{2}{|c|}{$\begin{array}{c}\text { Günde } \\
1 \text { saatten fazla } 2 \\
\text { saatten az (4) }\end{array}$} & \multicolumn{2}{|c|}{$\begin{array}{c}\text { Günde } \\
2 \text { saatten } \\
\text { fazla (5) }\end{array}$} \\
\hline & f & $\%$ & $f$ & $\%$ & $f$ & $\%$ & f & $\%$ & f & $\%$ \\
\hline Ödev yapma, ders çalışma & 26 & 9.4 & 33 & 11.9 & 63 & 22.8 & 84 & 30.3 & 71 & 25.6 \\
\hline Bahçede ve ya evde oynama & 107 & 38.5 & 33 & 11.9 & 33 & 11.9 & 51 & 18.3 & 54 & 19.4 \\
\hline $\begin{array}{l}\text { İnternette zaman geçirme/ } \\
\text { bilgisayarda oyun oynama }\end{array}$ & 93 & 33.6 & 42 & 15.1 & 56 & 20.1 & 51 & 18.3 & 36 & 12.9 \\
\hline Kitap okuma & 51 & 18.5 & 72 & 26.1 & 97 & 35.1 & 39 & 14.1 & 17 & 6.2 \\
\hline Tv izleme & 43 & 15.6 & 55 & 19.9 & 59 & 21.4 & 71 & 25.7 & 48 & 17.4 \\
\hline $\begin{array}{l}\text { Sanatsal etkinlikler (Resim } \\
\text { yapma, müzik dinleme...) }\end{array}$ & 103 & 37.3 & 60 & 21.7 & 59 & 21.4 & 31 & 11.2 & 23 & 8.4 \\
\hline
\end{tabular}

Yukarıdaki tablonun daha kolay anlaşılması ve yorumlanabilmesi için zaman dilimleri numaralandırılmış ve 1 saate kadar olan zaman dilimleri (1,2,3 nolu zaman dilimleri) birlikte, 1 saatten fazla zaman dilimleri ( 4 ve 5 nolu zaman dilimleri) birlikte ele alınmıştır. Buna göre bu veriler içerisinde aşağıdaki bulgular elde edilmiştir.

1. Öğrencilerin yarıdan fazlası (\%55.9) okul saati dışında günde bir saatten fazla ödev ve ders ile meşgul olurken \%44.10'u bir saatten az ders ve ödevle meşgul olmaktadır. Bu veriler içerisinde ankete katılan öğrencilerin \%25.6'sı, sekizinci sınıfların ise \%41'i bir günde iki saatten fazla ders çalıştığını belirtmiştir. Buda merkezi sınav gerçeğini ortaya koymaktadır.

2. Öğrencilerin $\% 62.3^{\prime} u$ günde bir saate kadar, \%37.7'si bir saatten fazla bahçede veya evde oyun oynamakta olduğunu belirtmiştir. Bunların içerisinde bazı günler veya hiç şıkkını seçen öğrenci oranı \%38.5'dir. Dolayısıyla bu veriler öğrencilerin oyuna ayırdığı vaktin oldukça sınırlı olduğunu göstermiştir.

3. Internette vakit geçirme/ bilgisayarda oyun oynama aktivitesini günde bir saate kadar yapan öğrenci oranı \%68.8, bir saatten fazla yapan öğrenci oranı \%31.2 olarak belirlenmiştir. Bu sonuç öğrencilerin internette vakit geçirme ve bilgisayarda oyun oynamaya kendilerinin fiziksel, ruhsal ve zihinsel gelişimi için önemli olan oyundan daha fazla zaman ayırdıkları görülmektedir. Bu sonuca neden olan etmenlerin iyi değerlendirilip gereken önlemlerin alınması zorunludur. Acaba çocuk bir alışkanlığın sonucu olarak mı yoksa fiziki yetersizlikten kaynaklı olarak mı oyuna bilgisayar ve internetten daha az vakit ayırdıkları incelenmesi gerekmektedir.

4. Kitap okumaya ve sanatsal etkinliklere diğer aktivitelere göre daha az zaman ayrıldığı görülmüştür. Buna göre kitap okumaya \%79.7, sanatsal etkinliklere (resim, müzik,..) \%80.4 oranında bir saate kadar zaman ayrıldığı tespit edilmiştir.

5. Televizyon izleme bakımından öğrenciler ders çalışma ve ödev yapmadan sonra en fazla tercih ettiği etkinlik olarak göze çarpmaktadır. Buna göre öğrencilerin \%43.1'i iki saatten fazla, \%56.9'u bir saate kadar televizyon izlediği belirlenmiştir.

6. Sonuçlar öğrencilerin en fazla ders çalışma ve ödev yapmaya, en az ise sanatsal etkinliklerle vakit geçirdiğini göstermektedir.

Cinsiyet ve sınıf değişkenlerinin ayrılan zaman miktarına etkisi Ki-kare bağımsızlık testiyle ayrıca analiz edilmiştir (Çizelge 3). Ki-kare bağımsızlık testi iki veya daha fazla sınıflı ölçekle ölçülmüş değişkenler arasında bağımlılık olup olamadığını belirlemek amacıyla kullanılmaktadır (Durmuş ve ark., 2012).

Çizelge 3 incelendiğinde ödev yapma, bahçede oynama, internette zaman geçirme ve sanatsal etkinliklere ayrılan zamana cinsiyetin etkisi, internette zaman geçirme, kitap okuma, Tv izleme ve sanatsal etkinliklere ayırılan zamana ise sınıf değişkeninin etkisi görülmektedir.

\section{Mekâna bağlı serbest zaman aktivite tercihleri ve rekreasyonel eğilimleri}

'Serbest zamanlarınızı en çok nerede geçirmekten hoşlanırsınız?' şeklindeki soruya cevap veren öğrencilerin \%23.8'i evde, \%59'u açık alanda (park, bahçe, evin/apartman önü...) ve \%17.2'si kapalı mekanda (ev dışında bir yer, alışveriş merkezi, kapalı oyun salonları ...) şeklinde cevap vermiştir. Öğrencilerin serbest zaman aktivitesi için dış mekân rekreasyonu, yani kentsel açık ve yeşil alan tercihi görülmektedir. 
Çizelge 3. Cinsiyet ve sınıf değişkeninin öğrencilerin aktivite sürelerine ayırdığı zaman arasında bağımlılık analizi (Pearson Chi-Square/Ki-kare).

\begin{tabular}{lcccccc}
\hline \multirow{2}{*}{ Aktivite Cinsi } & \multicolumn{3}{c}{ Cinsiyet } & \multicolumn{3}{c}{ Sınıf } \\
\cline { 2 - 7 } & $\mathbf{X}^{\mathbf{2}}$ & $\mathbf{d f}$ & $\mathbf{p}$ & $\mathbf{X}^{\mathbf{2}}$ & $\mathbf{d f}$ & $\mathbf{p}$ \\
\hline Ödev yapma, ders çalışma & 17.15 & 4 & $.002^{*}$ & 15.76 & 12 & .202 \\
Bahçede ve ya evde oynama & 17.46 & 4 & $.002^{*}$ & 12.76 & 12 & .387 \\
İnternette zaman geçirme/ bilgisayarda oyun oynama & 33.04 & 4 & $.000^{*}$ & 31.04 & 12 & $.002^{*}$ \\
Kitap okuma & 9.14 & 4 & .057 & 25.48 & 12 & $.013^{*}$ \\
Tv izleme & 2.19 & 4 & .700 & 31.38 & 12 & $.002^{*}$ \\
Sanatsal etkinlikler (Resim yapma, müzik dinleme...) & 14.05 & 4 & $.007^{*}$ & 22.61 & 12 & $.031^{*}$ \\
\hline
\end{tabular}

* p<.05, $\mathrm{H}_{1}$ Kabul; $H_{0}$ : Değişkenler birbirinden bağımsızdır. $H_{1}$ : Değişkenler birbirine bağımlıdır.

Serbest zaman etkinliklerinde mekân tercihleri ile ilgili yapılan diğer araştırmalarda Mansuroğlu (2002), Şahin ve ark. (2009), Talay ve ark. (2010), Sağlık ve Kelkit (2014) ve Vural (2016) dış mekânların iç mekânlara göre daha fazla tercih edildiğini belirtirken Cengiz ve Doğtaş (2015) ise iç mekân aktivitelerinin daha fazla tercih edildiğini belirlemiştir. Rekreasyonel mekân tercihlerinde Sağlık ve Kelkit (2014)'e göre araştırmaya katılanların \%47'si deniz kenarında, \%38.3 kentsel park alanları ve spor alanlarında, Talay ve ark. (2010)'e göre açık alan rekreasyonunu tercih edenlerin oranı \%86.3, Mansuroğlu (2002)'ye göre ise araştırmaya katılanların \%88.6'sı dış mekanlarda, \%6'sı iç mekanlarda serbest zamanlarını geçirmektedirler. Rakamsal farklılıklar olsa da yapılan benzer araştırmalar açık/dış mekân rekreasyonunun insanlar için daha fazla dinlendirici ve tercih edilir olduğunu göstermektedir. De Valck ve ark. (2017) Belika/Antwerp'te yaptığı araştırmada gençlerin rekreasyon aktivitesine katılım frekanslarını belirlemiş, araştırmaya katılanların \%26.5'inin yılda birkaç kez, \%28.7'nin ayda birkaç kez, \%26'nın haftada birkaç kez ve \%6.7'nin günde birkaç kez rekreasyonel faaliyet içerisinde bulunduklarını, \%12.1'inin ise hiçbir rekreasyonel faaliyete katılmadıklarını belirlemiştir. Vural (2016) ise öğrencilerin teneffüs saatleri için okul bahçesinin daha fazla tercih edildiğini belirlemiştir.

Diğer taraftan cinsiyet ve sınıf değişkenlerinin mekân tercihlerine etkisi üzerine yapılan Pearson Chi-Square (Ki-kare) analizinde ise cinsiyet ve sınıfın mekân tercihleri üzerine bir etkisinin olmadığı görülmüştür (Cinsiyet için; $X^{2}$ $=3,75, p>.05$, Sınıf için $X^{2}=6,58, p>.05$ ). Benzer olarak Mansuroğlu (2002)'de mekân tercihlerinde cinsiyetin bir etkisinin olmadığını belirlemişlerdir.

Bu soru ile bağlantılı olarak öğrencilere açık ve kapalı alan rekreasyon tercihleri de sorulmuştur. Buna göre; 'Açık alanda (park, bahçe, ev veya apartman önü) en çok tercih ettiğiniz aktivite nedir?' şeklindeki soruya verilen cevap yüzdeleri Şekil 2'de verilmiştir. Öğrencilerin açık alanda en fazla sportif aktiviteleri tercih ettiği, bunun yanında çevrede veya parkta serbestçe dolanma ve bisiklet sürme aktivitelerini de yüksek oranlarda tercih ettikleri görülmüştür. Benzer bir araştırmada okul bahçesinde öğrencilerin yer verilmesi istediği kullanımlar bakımından sportif alanlar en yüksek oranda (\%56.9) tercih edildiği görülmektedir (Vural, 2016).

Kapalı mekânda (evde, okulda) tercih edilen serbest zaman aktivitelerine bakıldığında aile ve akraba ile vakit geçirme, bilgisayar/telefonla oyun ve müzik dinleme veya müzik yapma en çok tercih edilen aktiviteler arasındadır (Şekil 3).

Cengiz ve Doğtaş (2015) ilköğretim öğrencilerine yönelik bir araştırmada öğrencilerin kapalı mekân serbest zaman aktivitesi olarak \%31înin bilgisayarla oynayarak, \%23'ünün televizyon izleyerek ve \%21'inin arkadaşları ile oynayarak vakit geçirdikleri belirlemiştir. Açık ve kapalı mekân rekreasyonu ile ilgili farklı hedef grupları ile yapılan çalışmalarda elde edilen sonuçların birbirine yakın olduğu görülmüştür. Bu çalışmalardan bazılarına örnek verilecek olursa; Kiper (2009)'a göre Tekirdağ Namık Kemal Üniversitesi öğrencilerinin \%74.5’i kültürel ve sosyal etkinlikleri, \%61.8'i dinlenmeye yönelik aktiviteleri ve $\% 58$ 'i doğaya yönelik aktiviteleri serbest zaman etkinliği olarak tercih etmektedir. Şahin ve ark. (2009) tarafından üniversite öğrencilerine yönelik yapılan anket sonucunda öğrencilerin \%67.1'i açık havada dolaşma, \%65.6'sı müzikle uğraşma, \%59.9'u internet ve bilgisayarla uğraşma, \%44.3'ü ise serbest zamanlarında sportif faaliyetlere katıldıklarını belirtmişlerdir. Kitt ve ark. (2014)'ün araştırmasında katılımcıların birinci derecede tercih ettiği serbest zaman aktivitesinin yürüme/yürüyüş (\%70.4) olduğu, diğerlerinin ise sırayla doğal ve kültürel kaynaklı manzaraların izlenmesi, kamp yapma ve doğayı araştırma olduğu bildirilmektedir. De Valck ve ark. (2017)'e göre ise doğal ortamlarda yürüme aktivitesine katılım oranı \%49.7, bisiklet sürme \%21, köpekle yürüme \%11.1 ve koşu yapma aktivitesi \%6.5 olduğu belirtilmektedir. 


\section{Açık alan aktivite tercih grafiği (\%)}

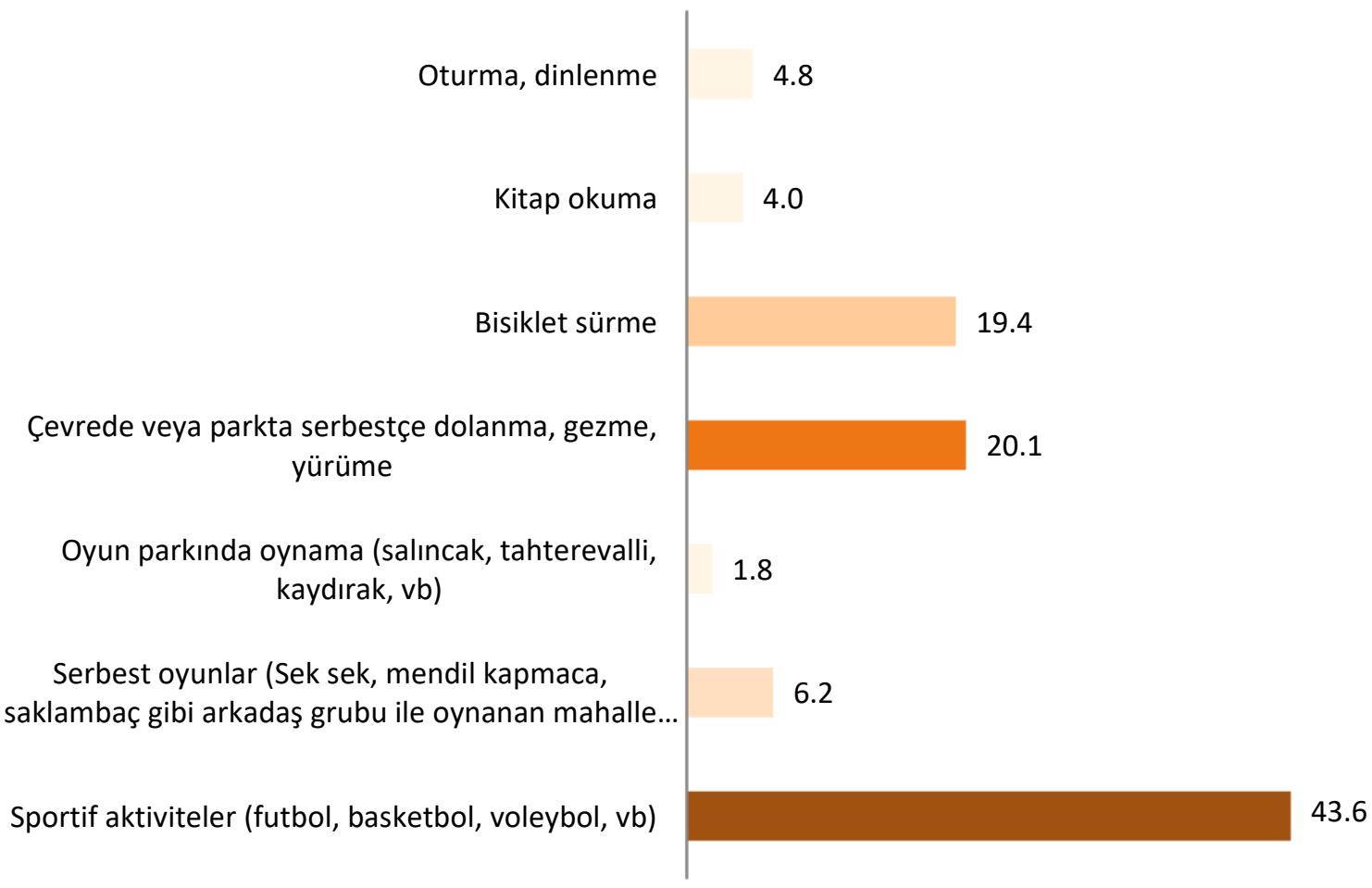

Şekil 2. Öğrencilerin açık alanda aktivite tercihleri.

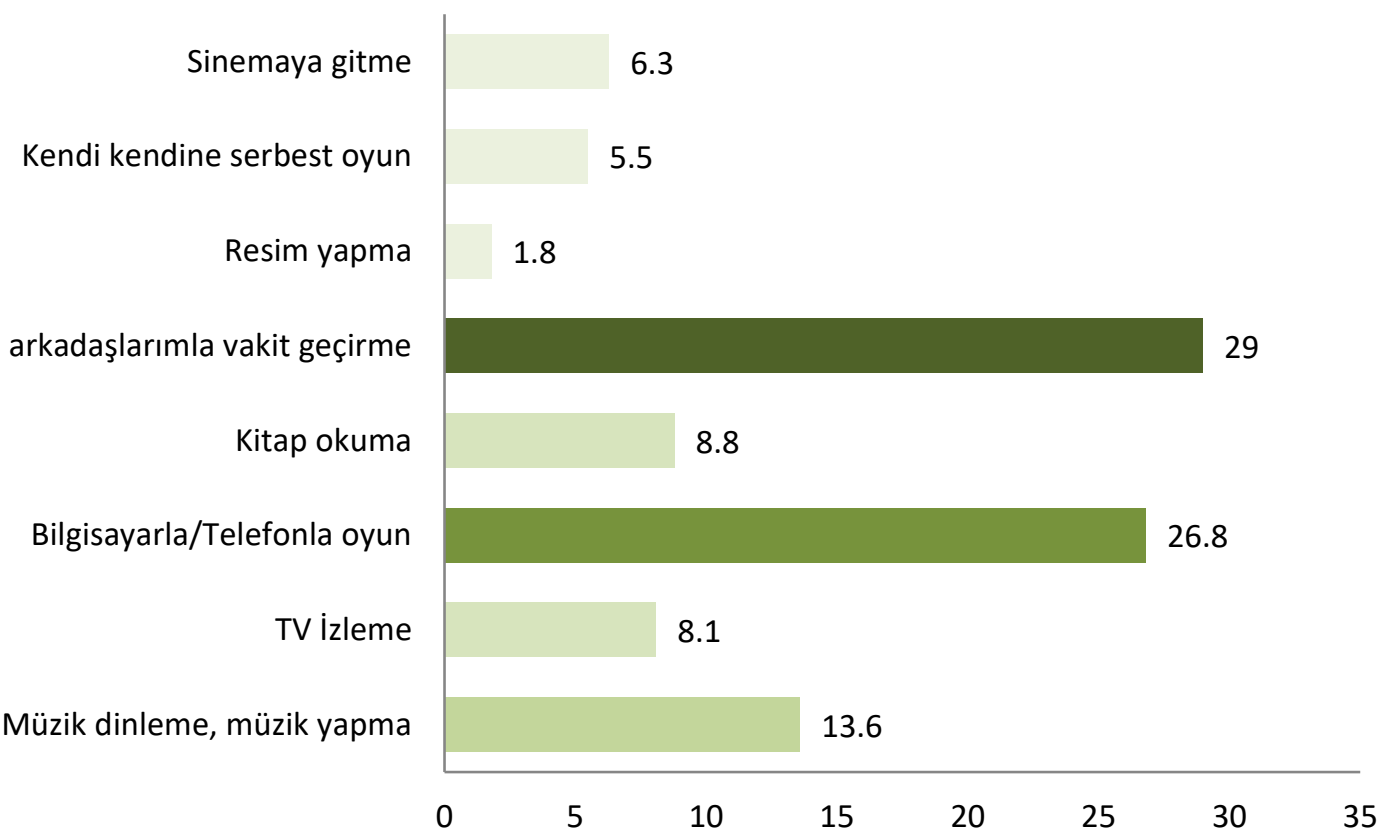

Şekil 3. Öğrencilerin kapalı alanda aktivite tercihleri grafiği (\%).

Öğrencilerin açık ve kapalı alan rekreasyonunda cinsiyet faktörünün etkisinin olup olmadığı da analiz edilmiştir. Kategorik veriler istatistik analiz yöntemi olan Ki-kare testine göre cinsiyetin hem açık alan rekreasyonu hem de kapalı alan rekreasyonel aktivite tercihlerinde anlamlı bir fark oluştuğu görülmüştür $\left(p<.05 ; X^{2}\right.$ (açık alan)= 45.52; $X^{2}$ (kapalı alan)= 42.45). Cinsiyete göre yapılan analizde açık alan aktivitesi olarak erkek öğrenciler en fazla sportif aktiviteleri (\%62.6) tercih 
ederken kız öğrenciler en fazla çevrede veya parkta dolanma, gezme ve yürüme aktivitesini (\%31.7) tercih etmektedir. Kızların sportif aktivite tercih oranı \%26.1, erkeklerin çevrede veya parkta dolanma, gezme ve yürüme aktivite tercih oranı \%7.6 olarak gerçekleşmiştir. Bir başka örnekte bisiklet sürme etkinliğini tercih edenler içerisinde kızların oranı \%24.6 iken erkeklerin oranı \%13.7 olarak tespit edilmiştir. Açık alanda erkeklerin daha çok fiziksel aktiviteye dayanan aktif rekreasyonu, kız öğrencilerin ise pasif rekreasyona dayanan aktiviteleri tercih ettiği görülmektedir.

Kapalı mekân aktivite tercihlerinde de kız ve erkek öğrenciler arasında fark görülmüştür. Erkek öğrenciler en fazla (\%43.8) bilgisayar veya telefonla oyunu tercih ederken kız öğrenciler en fazla (\%33.1) aile veya arkadaşıyla vakit geçirmeyi tercih etmiştir.

$\mathrm{Bu}$ konuda yapılan diğer araştırmalarda da benzer sonuçlar alınmış serbest zaman tercihleri ile cinsiyet arasında istatistiksel olarak anlamlı fark bulunmuştur. Ayaşlıgil ve Kubat (2005)'ye göre cinsiyet ile boş zamanlarında spor yapma ve oynama arasında anlamlı bir ilişki vardır. 18-44 yaş aralığında erkekler spor alanlarını kadınlara göre daha fazla tercih ettikleri bildirilmektedir. Sağlık ve Kelkit (2014)'e göre serbest zaman aktivite tercihlerinde cinsiyetin etkisi bulunmakta, erkekler gezi, yürüyüş, sportif faaliyetler ve evde dinlenmeyi tercih ederlerken kadınlar evde çalışmak, aktif-pasif kültürel uğraş, park gezisi, akraba ve arkadaş ziyareti gibi aktiviteleri tercih etmektedir. Benzer olarak Müderrisoğlu ve Uzun (2004), üniversite öğrencilerine yönelik araştırmasında açık alan rekreasyonunda cinsiyetin tercih üzerine etkisinin bulunduğu, kızların alış veriş yapma, kır gezisine katılma ve radyo dinleme etkinliğini, erkeklerin ise futbol, basketbol, voleybol, koşma, balık tutma gibi aktiviteleri daha fazla tercih ettiklerini belirlemiştir. Bir başka araştırmada kadınların erkeklere göre belirgin fark içeren rekreasyonel eğilimleri olarak; uzun doğa yürüyüşü, park gezintisi, çeşitli hobiler ve yürüyüş olarak gösterilmektedir (Talay ve ark., 2010). Ancak Tokgöz ve ark. (2015) tarafından ortaokul öğrencilerine yönelik yapılan araştırmada serbest zaman tercihlerinde cinsiyet bakımından istatistiksel olarak anlamlı bir fark görülmediği belirtilmektedir. Yukarıda veriler birlikte değerlendirildiğinde fizyolojik şartlar ve akademik çalışmalar göz önünde bulundurulduğunda cinsiyet ile serbest zaman değerlendirme biçimi arasında farkın olduğu ağırık kazanmaktadır. Dolayısıyla küçük ve büyük ölçekli fiziki düzenlemelerde cinsiyet faktörü göz önünde bulundurularak planlama yapılmalıdır.

Öğrencilere kendi tercihlerinin yanı sıra kendini stresli hisseden bir arkadaşının hangi aktiviteyi yapmasını önerdiği de sorulmuştur. Açık uçlu olarak sorulan bu soruya öğrencilerin verdiği cevaplar sınıflandırılarak aşağıdaki sonuçlar elde edilmiştir (Çizelge 4).

Çizelge 4. Öğrencilerin yakın bir arkadaşı için aktivite önerileri.

\begin{tabular}{clcc}
\hline S.N. & Önerdiği Aktivite & $\mathbf{f}$ & $\mathbf{\%}$ \\
\hline $\mathbf{1}$ & Açık havada yürüme, gezme, dolanma & 56 & 19.9 \\
$\mathbf{2}$ & Sportif faaliyetler (futbol, basketbol, voleybol....) & 26 & 9.2 \\
$\mathbf{3}$ & Oyun oynama & 26 & 9.2 \\
$\mathbf{4}$ & Doğal veya doğala yakın ortamlarda (botanik park, mahalle parkı, kentsel yeşil & 23 & 8.2 \\
& alanlar...vb) vakit geçirme & \\
$\mathbf{5}$ & Moral verme, motive edici konuşma yapma & 23 & 8.2 \\
$\mathbf{6}$ & Müzik dinleme & 20 & 7.1 \\
$\mathbf{7}$ & Sosyal aktivite (Sinema veya tiyatroya gitme) & 14 & 5.0 \\
$\mathbf{8}$ & Stres çarkı & 10 & 3.5 \\
$\mathbf{9}$ & Ailesi ile veya arkadaşları ile vakit geçirme & 9 & 3.2 \\
$\mathbf{1 0}$ & Kitap okuma & 9 & 3.2 \\
$\mathbf{1 1}$ & Diğer seçenekler & 45 & 16 \\
$\mathbf{1 2}$ & Cevap vermeyenler & $\mathbf{4}$ & $\mathbf{7 . 4}$ \\
\hline TOPLAM & & $\mathbf{2 1}$ \\
\hline
\end{tabular}

Buna göre öğrenciler yakın bir arkadaşına açık havada yürüme, gezme ve dolanma, sportif faaliyetler, oyun, doğal veya doğala yakın bir ortamda zaman geçirme aktivitelerini daha fazla tavsiye etmiştir. Açık uçlu sorulan bu soruda birçok faklı aktivite önerileri de 'Diğer seçenekler' başlığı altında toplanmıştır. Kendi istediği aktiviteyi yapması, uyuması, bulunduğu ortamdan uzaklaşması, resim yapması, yemek yemesi ve yalnız kalması gibi aktiviteler diğer seçenekler başlığı altında değerlendirilen aktivite önerileri arasında yer almaktadır.

Grahn ve Stigsdotter (2003) tarafından İsveç'te yapılan benzer bir araştırmada kendini stresli hisseden yakın bir arkadaşına katılımcıların sırasıyla ormanda yürüme, dinlendirici müzik, sakinleştirici ilaç, sessiz ve sakin bir parkta dinlenme ve kitap okuma gibi aktivite önerileri sundukları 
görülmüştür. Bununla beraber ankete katılanlar en fazla stres, sırt ağrısı ve yorgunluktan şikâyet ettikleri, yapılan analizler sonucunda kentsel açık ve yeşil alanlarda vakit geçirenlerin daha az strese maruz kaldıkları belirlenmiştir. Tyrvainen ve ark. (2014)'e göre de yoğun iş temposu sonunda kentsel yeşil alanlarda vakit geçirmenin stresi azaltmada önemli derecede etkisi olduğu vurgulanmıştır. Serbest zaman aktivitesi olarak fiziksel aktiviteye katılımın stresi azaltmada ve yaşam kalitesinin artmasında katkısı olduğu görülmüştür (Cortés ve ark., 2017). Ayrıca fiziksel aktiviteye katılımın artması öğrencilerin okul motivasyonuna ve akademik başarılarının artmasına katkı sağladığı belirlenmiştir (Vural ve Yılmaz, 2016).

Ancak serbest zaman, oyun ve rekreasyona ilişkin toplumsal bilincin tam olarak sağlandığı söylenmez. Bu konuda özellikle okul çağı öğrencilerinin olumsuz çevre baskısı ile karşı karşıya kaldığı görülmektedir. Gerek okulda görev yapan yönetici ve öğretmenler, gerekse de öğrenci velileri serbest zamanın, oyunun ve rekreasyonun öğrenciler için önemi konusunda bilinçlendirilmelidir. Nitekim Yaman ve Arslan (2009)'a göre; Dünya Serbest Zaman ve Rekreasyon Birliği'nin (World Leisure and Recreation Association) serbest zaman eğitimi ve risk altındaki gençlik üzerine yayınladığı uluslararası durum raporunda hem gençler, gençliğe yönelik çalışanlara (öğretmenler, yöneticiler, ebeveynler, vb.) mutlaka serbest zaman ve rekreasyon üzerine eğitim almaları gerektiği vurgulanmıştır.

\section{Sonuç ve Öneriler}

Öğrenciler, eğitim öğretim sezonunda zamanlarının büyük bir kısmını okulda ve evde eğitim öğretimle uğraşarak geçirdikleri için serbest zaman olarak çok az zamanları kalmaktadır. Özellikle son sınıfta okuyan öğrencilerin okul saati dışında iki saatten fazla ders çalıştıkları ve ödev yaptıkları, oyun, dinlenme, eğlenme, gibi temel ihtiyaçlara yeterince zamanlarının kalmadığı görülmüştür.

Araştırma kapsamında elde edilen diğer bir sonuç öğrencilerin serbest zaman aktiviteleri için dış mekânları tercih ettiği, aktivite olarak ise açık alan rekreasyonel faaliyetlerini daha fazla tercih ettikleri görülmüştür. Bununla beraber aktivite tercihlerinde cinsiyete bağlı olarak tercihlerin çeşitlendiği görülmüştür. Öğrenci tercihleri kent içi açık ve yeşil alanların önemini bir kez daha ortaya koymuştur. Bu nedenle araştırma sonuçları ışığında öncelikle öğrencilere daha fazla serbest zaman kazandırmak için eğitim öğretim faaliyetlerine yönelik yönetsel tedbirlerin alınması zorunludur. Özellikle okul saatleri içerisinde öğrencilerin en az bir veya iki ders saati serbest zamana yönlendirici derslerin konulması ve fiilen uygulanması gerekmektedir.

Serbest zamanın etkili ve verimli kullanımını etkileyen diğer bir husus ise serbest zamanın yapılacağı mekân ve imkânlardır. Buna yönelik olarak çocuğun yaşadığı konut ve çevresinden başlayarak bulunduğu mahallede, okulda, yaşadığı semtte, ilçede ve il bütününde cinsiyete yönelik tercihler göz önünde bulundurularak fiziki alt yapının iyileştirilmesi gerekmektedir. Özellikle kentsel açık ve yeşil alanların, doğal veya doğala yakın ortamların çocukların serbest zaman ihtiyaçlarını karşılayacak şekilde yürüme yolları, bisiklet sürme yolları, spor, oyun ve fiziksel aktivite alanları, hayvanat bahçesi, botanik bahçesi, akvaryum, dinlenme alanları, gözlem alanları, vb. imkânlarla iyileştirilmesi gerekmektedir.

a: Bu çalışma 9-11 Mart 2018 tarihleri arasında Mardin'de düzenlenen 1. Uluslararası IKSAD Sosyal Bilimler Kongresi'nde sözlü bildiri olarak sunulmuş ve özet bildiri olarak yayınlanmıştır.

\section{Kaynaklar}

Alqudah, Y.M.M. 2003. Çocuğun Gelişiminde Oyun Alanlarının Rolü. Ankara Üniversitesi Fen Bilimleri Enstitüsü Yüksek Lisans Semineri, Ankara.

Ardahan, F., Lapa, T.Y. 2011. Outdoor recreation: the Reasons and carried benefits for attending outdoor sports of the participants of cycling and/or trekking activities. Journal of Human Sciences, 8(1): 1327-1341.

Ayaşlıgil, T., Kubat, A. 2005. Boş Zaman eğilim ve rekreasyonel gereksinimlerin nüfus özelliklerine göre değişim ve farklılıklarının Çanakkale kenti örneğinde irdelenmesi. Journal of the Faculty of Forestry Istanbul University/ Istanbul Üniversitesi Orman Fakültesi Dergisi, 55(1): 47-66.

Cengiz, T., Doğtaş, S. 2015. Illköğretim çağındaki çocukların açık yeşil alan kullanım alışkanlıklarının belirlenmesi: Çanakkale örneği. JOTAF/Tekirdağ Ziraat Fakültesi Dergisi, 12(2): 57-67.

Corbin, H. 1970. Recreation Leadership. 3th Edition, New York: Prentice-Hall Inc.

Cortés, A.S, Correa-Díaz, A.M., Benjumea-Arias, M.L., Valencia-Arias, A., Bran-Piedrahita, L. 2017. Motivational Factors and effects associated with physical-sport practice in undergraduate students. Procedia-Social and Behavioral Sciences, 237: 811-815.

De Valck, J., Landuyt, D., Broekx, S., Liekens, I., De Nocker, L., Vranken, L. 2017. Outdoor Recreation in various landscapes: Which site 
characteristics really matter?. Land Use Policy, 65: 186-197.

Durmuş, B., Yurtkoru, E.S., Çinko, M. 2012. Sosyal Bilimlerde SPSS'le Veri Analizi. Beta Yayınları, 4.Baskı, 215 s., İstanbul.

Grahn, P., Stigsdotter, U.A. 2003. Landscape planning and stress. Urban Forestry \& Urban Greening, 2(1): 1-18.

Kalem, S, 2001. Doğal ve Kültürel Değerlerinin Korunabilmesi İçin Turizm Potansiyelinin Belirlenmesinde Bir Yöntem Yaklaşımı ve Kastamonu ïli Kıyı Bölgesi ve Yakın Çevresinde Uygulanması. A.Ü. Fen Bilimleri Enstitüsü, Doktora Tezi, Ankara.

Kil, N., Holland, S.M., Stein, T.V. 2014. Structural Relationships between environmental attitudes, recreation motivations, and environmentally responsible behaviors. Journal of Outdoor Recreation and Tourism, 7: 16-25.

Kiper, T. 2009. Namık Kemal Üniversitesi Ziraat Fakültesi (Tekirdağ) öğrencilerinin rekreasyonel eğilim ve taleplerinin belirlenmesi. JOTAF/Tekirdağ Ziraat Fakültesi Dergisi, 6(2): 191-201.

Mansuroğlu, S. 2002. Akdeniz Üniversitesi öğrencilerinin serbest zaman özellikleri ve dış mekan rekreasyon eğilimlerinin belirlenmesi. Mediterranean Agricultural Sciences, 15(2): 53-62.

Metin, T.C., Kesici, M., Kodaş, D. 2013. Rekreasyon olgusuna akademisyenlerin yaklaşımları. Journal of Yasar University, 8(30): 50215048.

Müderrisoğlu, H., Uzun, S. 2004. Abant İzzet Baysal Üniversitesi Orman Fakültesi öğrencilerinin rekreasyonel eğilimleri. Süleyman Demirel Üniversitesi Orman Fakültesi Dergisi, 2: 108121.

Ragheb, M.G., Tate, R.L. 1993. A behavioral model of leisure participation based on leisure attitude, motivation and satisfaction. Leisure Studies, 12(1): 61-70.
Sağlık, A., Kelkit, A. 2014. Çanakkale kent halkının rekreasyonel eğilim ve taleplerinin belirlenmesi. COMU Journal of Agriculture Faculty, 2(1): 27-36.

Şahin C. K, Akten S, Erol U. E 2009. Eğirdir Meslek yüksekokulu öğrencilerinin rekreasyon faaliyetlerine katılımlarının Belirlenmesi Üzerine Bir Çalışma. Artvin Çoruh Üniversitesi Orman Fakültesi Dergisi, 10(1): 62-71.

Talay, i., Kaya, F., Belkayalı, N. 2010. SosyoEkonomik Yapının Rekreasyonel Eğilim ve Talepler Üzerine Etkisi: Bartın Kenti Örneği. Coğrafi Bilimler Dergisi, CBD, 8(2): 147-156.

Tokgöz, M., Demiroğlu, B., Aslan, Y. 2015. Ortaokul öğrencilerinin serbest zaman tercihlerinin cinsiyet değişkenine göre incelenmesi. Uluslararası Multidisipliner Akademik Araştırmalar Dergisi,2(3): 29-44.

Tyrväinen, L., Ojala, A., Korpela, K., Lanki, T., Tsunetsugu, Y., Kagawa, T. 2014. The influence of urban green environments on stress relief measures: A field experiment. Journal of Environmental Psychology, 38: 19.

Ünal, M. 2009. Çocuk gelişiminde oyun alanlarının yeri ve önemi. Inönü Üniversitesi Eğitim Fakültesi Dergisi, 10018(2): 99-110.

Vural, H., Yılmaz, S. 2016. İyileştirilmiş fiziksel çevre şartlarının ilkokul öğrencilerinin gelişimine etkisinin öğretmen gözüyle değerlendirilmesi. Bayburt Eğitim Fakültesi Dergisi, 11(2): 518-535.

Vural, H. 2016. Erzurum Kenti Okul Bahçelerinin Fiziki Yeterlilikleri ve Peyzaj Tasarım Sonrası Eğitime Katkılarının Analizi. Atatürk Üniversitesi Fen Bilimleri Enstitüsü, Doktora Tezi (Basılmamış), Erzurum.

Yaman, M., Arslan, S. 2009. Çocuk ve gençlik suçlarının önlenmesinde rekreatif sporlar. Uluslararası Insan Bilimleri Dergisi, 6(1): 445459. 